\title{
Reconstruction of parietal bone defects with adipose- derived mesenchymal stem cells. Experimental study ${ }^{1}$
}

\author{
Diego Dias da Silva' (iD, Ana Helena da Rosa Paz" (iD, Ciro Paz Portinho"I' (ID, Elizabeth Obino Cirne Lima'v (iD, \\ Lúcia Maria Kliemann ${ }^{\mathrm{V}}$ iD, Marcus Vinicius Martins Collares ${ }^{\mathrm{VI}}$ (iD)
}

' MSc, Postgraduate Program in Surgical Sciences, Universidade Federal do Rio Grande do Sul, Porto AlegreRS, Brazil. Design of the study, analysis of data, technical procedures, manuscript writing.

"PhD, Assistant Professor, Department of Morphological Sciences, Universidade Federal do Rio Grande do Sul, Porto Alegre-RS, Brazil. Design of the study, analysis of data, technical procedures, manuscript writing.

IIIPhD, Assistant Professor of Surgery, Universidade Federal do Rio Grande do Sul, Porto Alegre-RS, Brazil. Design of the study, analysis of data, manuscript writing.

IV PhD, Associate Professor, School of Veterinary Medicine, Universidade Federal do Rio Grande do Sul, Porto Alegre-RS, Brazil. Design of the study, analysis of data, technical procedures, manuscript writing.

${ }^{\vee}$ PhD, Assistant Professor of Pathology, Hospital de Clínicas de Porto Alegre, Universidade Federal do Rio Grande do Sul, Porto Alegre-RS, Brazil. Design of the study, histological examinations.

VIPhD, Associate Professor of Surgery, Universidade Federal do Rio Grande do Sul, Porto Alegre-RS, Brazil. Design of the study, analysis of data, manuscript writing.

\begin{abstract}
Purpose: This study assessed the regeneration potential of mesenchymal stem cells (MSC) from adipose tissue associated with platelet-rich plasma (PRP) in bone regeneration.

Methods: Thirty Wistar rats (Rattus norvegicus albinos) were divided into five groups (according to the grafting material and time to euthanasia): (1) autograft- 14 days (control), (2) autograft- 28 days (control), (3) MSC + PRP- 14 days, (4) MSC + PRP + papaverine- 14 days and (5) MSC + PRP + papaverine - 28 days. After euthanasia, the graft was removed and histological slides were prepared. They were assessed by a blinded pathologist using a previously published histological scale as parameter.

Results: There was some degree of neoformed bone trabeculae (NBT) in 93.3\% of the samples, as well as osteoblastic activity (OA). The autograft groups (14 and 28 days) had higher levels in the formation of bone trabeculae. Nonparametric data were analyzed using the Wilcoxon-Mann-Whitney test and proved not to be statistically significant at $p<0.05$.

Conclusion: Experimental parietal bone reconstruction, combining MSC, PRP and papaverine presented regeneration in all groups with no significant difference among them.
\end{abstract}

Key words: Bone Regeneration. Platelet-Rich Plasma. Tissue Engineering. Rats. 


\section{- Introduction}

Tissue engineering aims to develop new sources or ways of providing tissue for the reconstruction of destructed or damaged body areas ${ }^{1,2}$. In the craniofacial reconstructions there can be difficulties in obtaining bone grafts. It occurs mainly when there are extensive areas of bone loss or deformity, or when it is a case of multiple interventions ${ }^{3}$.

Although many synthetic substitutes have been produced, cell grafts remain the best choice, with greater capacity of integration and regeneration ${ }^{3,4}$. Several works on tissue engineering show that, in order to obtain the ideal means for bone regeneration, the graft must have cells with osteogenic potential, osteogenic growth factors and a matrix that serves as a mechanic mold (scaffold) to facilitate cellular revascularization and the tissue architecture ${ }^{3-6}$.

Even though bone marrow stem cells are the object of many studies and research, its clinical use requires elaborate procedures, which refer patients to procedures with a certain degree of morbidity due to their locations. Besides, the availability of the tissue for removal is scarce ${ }^{3,7}$.

With the discovery in the early 2000's of a new source of adipose-derived mesenchymal stem cells (ADSC), new clinical perspectives have been presented due to the greater availability of tissue for removal, since fat is easily located. Moreover, the removal process has lower morbidity and is already routine in plastic surgery, which leads to a greater acceptance among patients ${ }^{8-10}$. Studies in animal models demonstrate osteogenesis capacity of the ADSC ${ }^{3,11}$. Lendeckel et al. ${ }^{12}$ reported the use of ADSC and fibrin glue as coadjuvants to grafts in the treatment of a calvary defect.

The platelet-rich plasma (PRP) is an autologous platelet concentrate that presents growth factors and proteins with osteoconductive properties, which acts on epithelial migration and on bone and connective tissues formation ${ }^{13,14}$. It is obtained after blood processing, via differential centrifugation, which enables blood cell separation ${ }^{15-17}$. Platelet-rich plasma gel is achieved by addition of thrombin and calcium gluconate, which activates the coagulation system, thus generating a gelatinous product that facilitates its surgical application, also enabling platelet activation ${ }^{18,19}$. Platelets act in hemostasis, wound healing and reepithelization. Besides, the presence of growth factors, released by them, acts on angiogenesis, promoting vascular growth, fibroblasts proliferation and a consequent increase in collagen synthesis ${ }^{13,20}$.

Platelet-rich plasma has been studied in medicine and odontology and employed in bone graft surgeries in the alveolar area, in implantology, and periodontal and maxillofacial surgeries $^{13,21}$. In a clinical study with a sample of 20 patients who underwent dental extraction before the insertion of implants, Anitua reported that the alveoli treated with PRP presented greater buccolingual thickness at the moment of inserting the implants. Reepithelization was also better when compared with the group that did not receive PRP ${ }^{16}$.

The studies in medicine demonstrate great potential of PRP in improving the results of orthopedic and neurosurgical procedures, as well as of those in plastic surgery ${ }^{20,22-24}$. In rhytidoplasty, abdominoplasty and mammoplasty surgeries and when there is the presence of skin flaps, PRP helps in hemostasis and stimulates neovascularization, thus decreasing complications, such as hematomas, seromas and flap suffering ${ }^{22,24}$. This study aims to assess the potential of the association of ADSC (extracted from the gonadal fat of rats, isolated, cultivated and expanded in laboratory) with a PRP scaffold and papaverine (a vasodilator drug) as a bone substitute.

\section{- Methods}

This is an open, compared, prospective experimental study conducted in the Universidade Federal do Rio Grande do Sul (UFRGS) and Hospital de Clínicas de Porto Alegre (HCPA). The participating units were the Unit of Craniomaxillofacial Surgery of the Division of Plastic Surgery of HCPA, the Laboratory of Embryology and Cellular Differentiation of HCPA, the Unit of Animal Experimentation (UEA) at the Center of Experimental Research (CPE) of HCPA and the Department of Pathology of the Medical School of UFRGS and the Unit of Experimental Pathology Unit of HCPA.

All procedures were reviewed and approved by HCPA Ethics Committee, which follows the rules for animal experimentation, advised by the Council for International Organization of Medical Sciences (CIOMS). This study is in accordance to the Animal Research: Reporting of In Vivo Experiments (ARRIVE) guidelines statement.

Thirty adult male Wistar rats with an average of 74 days-old and average weight of $302.24 \mathrm{~g}$ were included. The study groups were divided as follows:

- Group 1: Autograft and euthanasia in 14 days (SG 14);

- Group 2: Autograft and euthanasia in 28 days (SG 28);

- Group 3: ADSC graft + PRP and euthanasia in 14 days (ADSC + PRP 14);

- Group 4: ADSC graft + PRP + papaverine and euthanasia in 14 days (ADSC + PRP + PPV 14);

- Group 5: ADSC graft + PRP + papaverine and euthanasia in 28 days (ADSC + PRP + PPV 28).

\section{Experimental model of bone defect}

Anesthesia was administered to the Wistar rats with ketamine [100 mg/kg intraperitoneal; Vetbrands, Jacareí (SP), Brazil] and xylazine [10 $\mathrm{mg} / \mathrm{kg}$ subperitoneal; Vetbrands, Jacareí (SP), Brazil]. Local anesthetic was bupivacaine $0.5 \%(1 \mathrm{mg} / \mathrm{kg})$. After that, trichotomy 
was conducted in the area, leaving the head exposed. lodophor aqueous solution was applied over the animal's head for antiseptics, isolating the operative region with sterile fields.

An incision was made in the shape of a scythe in order to isolate the graft area from contact with the incised and sutured area. Then, the flap was lifted and the skullcap periosteum was scraped with a scalpel blade in the site of the future defect. Next, the size of the defect was marked with a sterile pen.

Total thickness bone defects were created (with a flexible, double-face, cutting, diamond disc; KG Sorensen, Brazil) in the region of the parietal bone, to be reconstructed in the same surgical time, according to each study group. After that, a delicate periosteal dissector was employed to open the defect, minimizing meningeal laceration.

After the removal of the portion of the skull cap, the graft was added, according to the group in question, and the scalp was closed with a simple suture stitch (4-0 or 5-0 nylon). Next, the animals were placed in appropriate incubator for surgical recovery, at $37^{\circ} \mathrm{C}$.

In the postoperative period, the animals were kept in cages with cycles of $12 \mathrm{~h}$ of light, with access to water and food ad libitum. Analgesia was conducted with tramadol [1 mg/kg, intramuscular, 8/8 h, two doses; Carlo Erba SA., Duque de Caxias (RJ), Brazil].

The animals were euthanized at the postoperative either 14 or 28 days' time point in a $\mathrm{CO}_{2}$ camera [Biotécnicas, São Paulo (SP), Brazil], according to the routine at the Unit of Animal Experimentation at the CPE, HCPA. We decided on those periods because it has been demonstrated that graft osteogenesis starts from two to four weeks ${ }^{25}$.

\section{Isolation of mesenchymal stem cells}

Two adult Wistar rats weighing approximately $300 \mathrm{~g}$ were used as tissue donors for cell isolation. The gonadal fat was collected and then processed in the Laboratory of Embryology and Cellular Differentiation (CPE at the HCPA).

After the euthanasia of the animals, the adipose tissue was removed under sterile conditions and processed in a laminar flow cabinet. Next, the tissue was put in collagenase solution type I [0.5 mg/mL in Dulbecco's modified Eagle's medium (DMEM) $10 \mathrm{mM} \mathrm{HEPES]} \mathrm{for} \mathrm{a} \mathrm{period} \mathrm{of} 45$ minutes at $37{ }^{\circ} \mathrm{C}$ to promote tissue digestion. After the complete digestion, the enzyme was inactivated by the addition of DMEM supplemented with $10 \%$ of fetal bovine serum (FBS).

After isolation, the cells were cultivated in DMEM, containing low concentration of glucose (Invitrogen, CA, USA), supplemented with $15 \mathrm{mM}$ Hepes, 15\% fetal bovine (Invitrogen, CA, USA) and antibiotic solution of 100 units $/ \mathrm{mL}$ of penicillin and $100 \mathrm{mg} / \mathrm{mL}$ of streptomycin (Gibco,
NM, USA) at $37{ }^{\circ} \mathrm{C}$ in atmosphere of $5 \% \mathrm{CO}_{2}$ and $100 \%$ humidity. After $24 \mathrm{~h}$ of cultivation, the culture medium was aspirated and half a flask was added. When the cell culture presented a confluence of $80 \%$, the adherent cells were removed with a solution of $0.05 \%$ trypsin-EDTA (Gibco, NM, USA) for posterior subculture in DMEM with $10 \%$ FBS (complete medium).

After the second passage of the cells, they could already be grafted. The cells were preserved, frozen and 5 days before the surgery were defrosted and prepared for grafting.

\section{Characterization of the culture of mesenchymal stem cells}

Based on the consensus published by the International Society for Cellular Therapy, the ADSC used in this work was characterized according to morphology, immunophenotyping and differentiation in vitro.

The immunophenotypic analysis consisted of a panel of antibodies for positive and negative selection. The expressions of CD90, CD29 and CD34 were tested. The antibodies were used in 1:100 dilution. The analyses were conducted on the flow cytometer BD FACSCalibur (Becton \& Dickinson, NJ, USA) from the Department of Biochemistry at UFRGS and the results were analyzed via software Paint-A-Gate.

The in vitro differentiation was performed. Three different experiments were conducted for the ADSC differentiation induction: osteogenic, adipogenic and chondrogenic differentiation. For the osteogenic differentiation, the DMEM 15 mM Hepes induction medium was used, supplemented with $10^{-8} \mathrm{~mol} / \mathrm{L}$ of dexamethasone (Sigma, MO, USA), $5 \mu \mathrm{g} / \mu \mathrm{L}$ of Ascorbic acid 2-phosphate (Sigma, MO, USA) and $10 \mathrm{mM} / \mathrm{L}$ of $\beta$-Glycerophosphate (Sigma MO, USA) in ADSC culture up to 21 days. Osteogenic differentiation was detected by alizarin red staining [Nuclear, Sao Paulo (SP), Brazil], which stains the extracellular matrix rich in calcium. For the adipogenic differentiation, the ADSC was cultivated in DMEM $15 \mathrm{mM}$ Hepes, $10^{-8} \mathrm{~mol} / \mathrm{L}$ of dexamethasone (Sigma, MO, USA), $5 \mu \mathrm{g} / \mathrm{mL}$ of insulin and $50 \mu \mathrm{g} / \mathrm{mL}$ of indomethacin (Sigma, MO, USA). The adipogenic differentiation was detected 21 days after the beginning of the differentiation test via staining with Oil Red (Sigma, MO, USA), which stains the fat vacuole. In the chondrogenic differentiation, a DMEM $15 \mathrm{mM}$ medium was used, supplemented with Hepes $6.25 \mathrm{ug} / \mathrm{mL}$, insulin $10 \mathrm{ng} / \mathrm{mL}$, transforming growth factor (TGF) beta1 and $50 \mathrm{nM}$ ascorbic acid 2-phosphate. The detection of differentiation was conducted through staining with Alcian Blue, which has affinity for the anionic groups present in the glycosaminoglycans of the extracellular matrix. 


\section{Preparation of platelet-rich plasma-protocol of} Sonnleitner

The blood collection for the production of the PRP gel was done in the immediate preoperative (after the anesthesia) according to the Sonnleitner protocol ${ }^{26}$. With the use of a microhematocrit, $1 \mathrm{~mL}$ of blood was collected from the retro-orbital plexus directly in an Eppendorf flask containing sodium citrate to prevent coagulation. Next, it was briefly agitated and put in a centrifuge for $20 \mathrm{~min}$ at $760 \mathrm{RPM}(160 \mathrm{G})$. At the end of the process, three components were obtained inside the tube, separated in layers. The red blood cells on the bottom, the PRP in the middle and the platelet-poor plasma (PPP) on top. The middle and superior parts of the tube were removed with a pipette (penetrating lightly the red blood cell layer in order to effectively collect the PRP) for a new Eppendorf and centrifuged again.

Centrifugation was repeated for 15 minutes at 1200 RPM (400 G). Previously, it had been 20 minutes at 760 RPM (160 G). After that, calcium gluconate was added and, after 10 more minutes, the consistency of gel was obtained, which is characteristic of fibrin glue.

\section{Transplant of the cells}

After the conclusion of the bone defect and the PRP gel preparation, the cells contained in an Eppendorf tube were removed with a pipette and added to the tube with the PRP gel. The cellular concentration in each sample was approximately $5 \times 10^{5}$ cells $/ \mathrm{mL}$. Then the graft was placed on the defect and, according to the group, papaverine (0.05 mL/sample) was added.

\section{Histological analysis}

After the euthanasia, the grafted areas were removed to enable the histological analysis. The removed grafted areas were put in formalin and sent to the Unit of Experimental Pathology for histological preparation and posterior staining with hematoxylin-eosin (HE). The removed graft was dried and fixated in formalin at $10 \%$. Next, the material was descaled in nitric acid solution at $10 \%$ for a minimum period of $24 \mathrm{~h}$. The material was cut longitudinally in slices and totally underwent the routine histological processing. From each block 4-micra thick cuts were stained in $\mathrm{HE}$ and then 30 slides were produced.

The histological analysis was conducted using the modified histological scale of Portinho ${ }^{27}$ (Table 1). From the original scale, the parameters of neoformed bone trabeculae (NBT) and osteoblastic activity (OA) were analyzed.
Table 1 - Histological scale.

\begin{tabular}{|c|c|c|}
\hline Criterium & Score & Score description \\
\hline \multirow[t]{4}{*}{$\begin{array}{l}\text { Neoformed } \\
\text { bone } \\
\text { trabeculae } \\
\text { (NBT) }\end{array}$} & 0 & $\begin{array}{l}\text { Absence of neoformed } \\
\text { trabeculae }\end{array}$ \\
\hline & 1 & $\begin{array}{l}\text { Thin, isolated trabeculae, } \\
\text { not surpassing } 1 / 3 \text { of the } \\
\text { microscope field }\end{array}$ \\
\hline & 2 & $\begin{array}{l}\text { Isolated or anastomosing } \\
\text { trabeculae, occupying } 1 / 3 \text { to } 2 / 3 \\
\text { of the microscope field. }\end{array}$ \\
\hline & 3 & $\begin{array}{l}\text { Thick trabeculae, } \\
\text { predominantly anastomosing, } \\
\text { occupying more than } 2 / 3 \text { of } \\
\text { the microscope field }\end{array}$ \\
\hline \multirow[t]{4}{*}{$\begin{array}{l}\text { Osteoblastic } \\
\text { activity }(\mathrm{OA})\end{array}$} & 0 & Nonexistent activity \\
\hline & 1 & $\begin{array}{l}\text { Less than } 1 / 3 \text { of the neoformed } \\
\text { trabeculae presents } O A\end{array}$ \\
\hline & 2 & $\begin{array}{l}\text { Activity observed in } 1 / 3 \text { to } 2 / 3 \\
\text { of the NBT }\end{array}$ \\
\hline & 3 & $\begin{array}{l}\text { More than } 2 / 3 \text { of the neoformed } \\
\text { trabeculae present OA }\end{array}$ \\
\hline
\end{tabular}

Modified from Portinho ${ }^{27}$.

\section{Statistical analysis}

The groups were analyzed with the Wilcoxon-MannWhitney test, for the NBT and OA, since the variables presented a nonparametric distribution.

\section{Sample size estimation}

The sample size estimation was performed in PEPI version 4.0 and based on Portinho's study ${ }^{27}$. For a significance level of $5 \%$, a variance of 10 with a $5 \%$ margin of error, a minimum total of 30 animals was estimated.

\section{- Results}

The immunophenotyping profile of adipose tissue derived stem cells used in the study is depicted in Fig. 1. Flow cytometry histograms revealed that $93.20 \%$ are negative for CD34. Also, $98 \%$ of the cells are positive for CD90 and $95.82 \%$ are positive for CD29. This is consistent with the immunophenotyping profile of adipose tissue derived stem cells. 

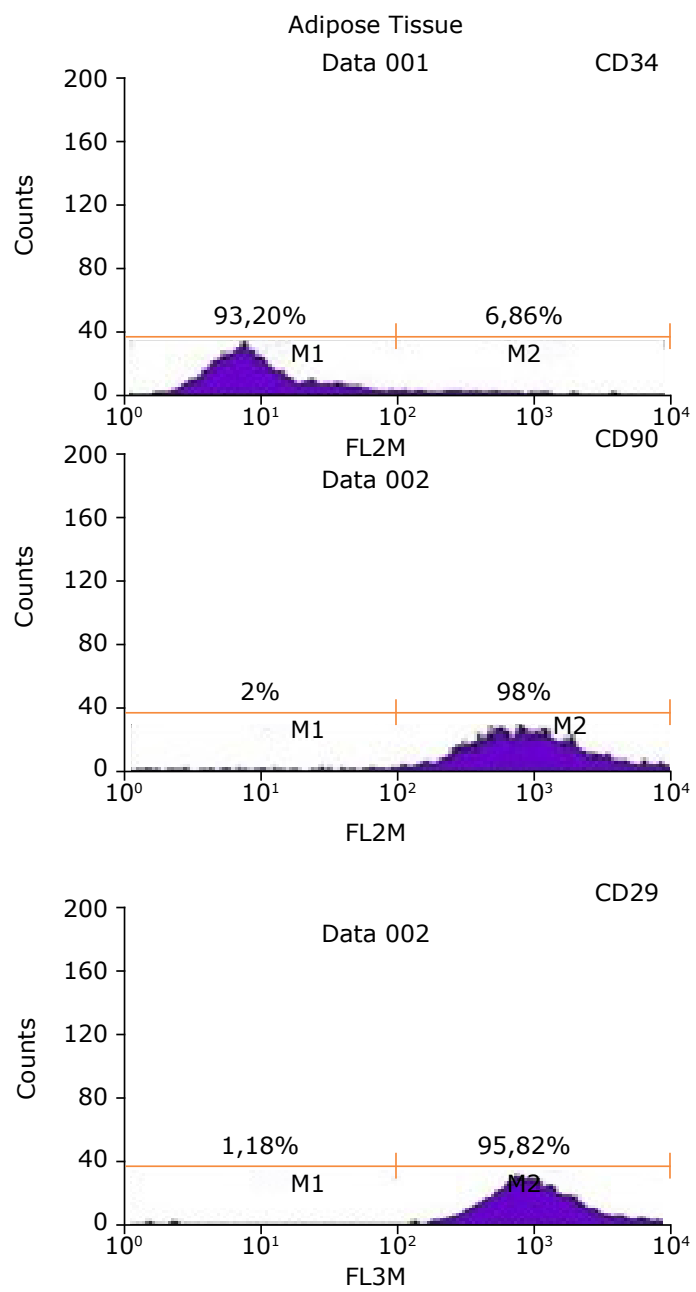

Figure 1 - Immunophenotypic profile of MSCs derived from different sources. Flow cytometry histograms show the expression of selected molecules (CD34, CD90 and CD29).

Mesenchymal stem cells (MST) differentiation from adipose tissue is illustrated in Fig. 2 . The MST were cultivated in adipogenic, chondrogenic and osteogenic media.
Groups 1, 3 and 4 (euthanasia in 14 days) were compared, as well as groups 2 and 5 (euthanasia in 28 days). Some degree of NBT was obtained in $93.3 \%$ of the total sample, as well as OA (score 1,2 or 3 on Portinho ${ }^{27}$ modified histological scale). The $6.7 \%$ that did not present NBT nor OA belonged to group 5 (Tables 2 and 3 ).

Table 2 - Frequency of neoformed bone trabeculae.

\begin{tabular}{lcc}
\hline Histological score & $\mathbf{n}$ & $\%$ \\
\hline 0 & 2 & 6.7 \\
$\geq 1$ & 28 & 93.3 \\
Total & 30 & 100 \\
\hline
\end{tabular}

0 = no trabecula formed; $\geq 1$ = there was trabecular formation.

Table 3 - Frequency of osteoblastic activity.

\begin{tabular}{lcc}
\hline Score & $\mathbf{n}$ & $\%$ \\
\hline 0 & 2 & 6.7 \\
$\geq 1$ & 28 & 93.3 \\
Total & 30 & 100 \\
\hline
\end{tabular}

$0=$ no activity $\geq 1$ = activity present.

Groups 1 and 2 (Autograft 14 and 28 days, respectively) presented better levels of NBT than group 3 (ADSC + PRP 14 days), 4 (ADSC + PRP + PPV 14 days) and 5 (ADSC + PRP + PPV 28 days) (Table 4). Osteoblastic activity was higher in groups 1 and 4 in comparison to groups 2 , 3 and 5 (Table 5). However, the differences observed in the NBT and OA parameters were not statistically significant $(p<0.05)$. (a)

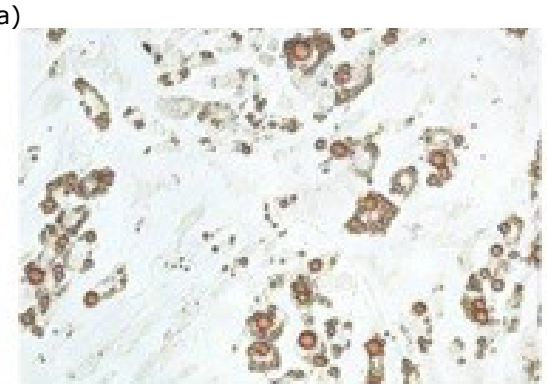

(b)

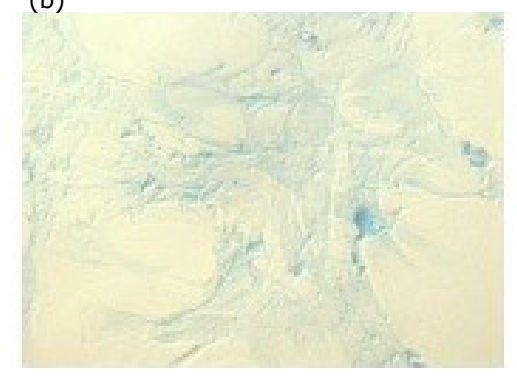

(c)

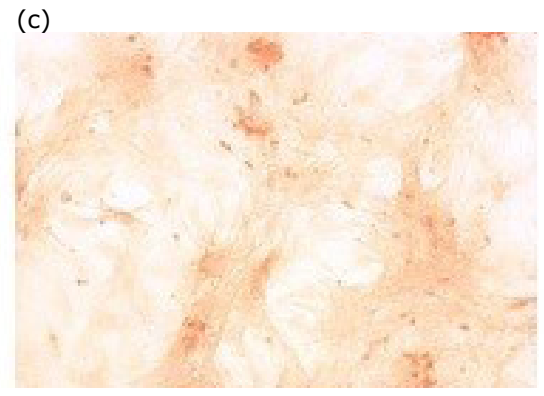

Figure 2 - Differentiation of MSCs from adipose tissue. Mesenchymal stem cells were cultured in adipogenic, chondrogenic and osteogenic medium. Lipid vacuoles are stained orange with Oil Red O. (a) Sulfated proteoglycans deposits are stained blue with Alcian Blue. (b) Calcium deposited in the extracellular matrix is stained red by Alizarin Red. (c) Magnifications and cell lines are indicated below each image. 
Table 4 - Median of the score for the histological criterium of NBT, by group.

\begin{tabular}{lcc}
\hline Group & Description & Median \\
\hline 1 & AG 14 & 2 \\
2 & AG 28 & 2 \\
3 & PRP + SC 14 & 1 \\
4 & PRP + SC + PPV 14 & 1 \\
5 & PRP + SC + PPV 28 & 1 \\
\hline
\end{tabular}

AG: autograft; SC: stem cells; PPV: papaverine; PRP: platelet rich plasm.

Table 5 - Median of the score for the histological criterium of $O A$, by group.

\begin{tabular}{lcc}
\hline Group & Group & Median \\
\hline 1 & AG 14 & 3 \\
2 & AG 28 & 2 \\
3 & PRP + SC 14 & 2 \\
4 & PRP + SC + PPV 14 & 3 \\
5 & PRP + SC + PPV 28 & 2 \\
\hline
\end{tabular}

AG: autograft; SC: stem cells; PPV: papaverine; PRP: platelet rich plasm.

The difference between autograft and cellular groups did not prove to be statistically significant for the parameters of bone trabeculae $(\mathrm{G} 1 \times \mathrm{G} 3, \mathrm{p}=0.097 ; \mathrm{G} 1 \times \mathrm{G} 4, \mathrm{p}=0.530$; $\mathrm{G} 2 \times \mathrm{G} 5, \mathrm{p}=0.268)$. Considering the $\mathrm{OA}$, no significant difference was found among the groups $(G 1 \times G 3, p=0.620$; $\mathrm{G} 1 \times \mathrm{G} 4, \mathrm{p}=0.876 ; \mathrm{G} 2 \times \mathrm{G} 5, \mathrm{p}=0.639)$.

A significant difference was not found between the groups with or without papaverine in relation to the formation of bone trabeculae $(G 3 \times G 5, p=0.755)$. Concerning $O A$, no statistically significant difference was detected either $(\mathrm{G} 3 \times \mathrm{G} 5, \mathrm{p}=1.000)$.

\section{- Discussion}

The majority of the prior studies utilized mesenchymal bone marrow-derived stem cells (BMSC). Adipose-derived mesenchymal stem cells were used due to the advantage of the adipose tissue being abundant and easy to obtain. Besides, obtaining BMSC is more difficult than ADSC and the procedure is more morbid for the patient ${ }^{8,9}$. Several authors showed that the ADSC could differentiate into pluripotential cells and produce bone tissue in vitro and in vivo ${ }^{3,8,9,28,29}$.

There was formation of bone trabeculae in $93.3 \%$ of the total study sample, with a distribution of that phenomenon through all the analyzed groups. In $6.7 \%$ of the sample ( 2 slides), there was no bone formation (score 0 on the modified histological scale of Portinho ${ }^{27}$ ); both belonged to group 5 (ADSC + PRP + PPV 28 days).
In the groups involving stem cells (60\% of the samples, 18 out of 30 animals), we obtained (in $88.9 \%, 16$ of 18 samples) some degree of formation of bone trabeculae, which demonstrates the osteogenic potential of the ADSC already reported in the literature ${ }^{3,12,27,30}$. In the group involving autograft, the formation of bone trabeculae was $100 \%$. That is in accordance with the literature, where autograft, for its properties of osteoconduction, osteoinduction and osteogenesis, remain the gold standard ${ }^{27,31}$.

The autograft groups (groups 1 and 2) performed better in the NBT when compared with the groups with cells (groups 3,4 and 5), but there was no statistical difference ${ }^{32-36}$. That might have occurred in part for the small size of each group (six animals per group), although the calculus of the sample allowed that population. Also, the PRP scaffold may not be the best cell carrier, albeit that is still to be studied.

As for the OA parameter, as well as the NBT, the autograft group presented $100 \%$ of activity to $88.23 \%$ of the groups with cells and the samples that did not present OA belonged to group 5 .

Groups 1 (AG 14 days) and 4 (ADSC + PRP + PPV 14 days) obtained better scores in comparison to groups 2, 3 and 5 . Osteoblastic activity can be an important element since, in spite of the low neoformation of bone trabeculae in the groups with cells $(3,4$ and 5$)$, those trabeculae presented an OA equivalent to the autograft 28 days, in groups 3 and 5 and equivalent to group AE 14 days in group 4.

Since the $\mathrm{OA}$ is an indicator of bone cellular activity in the region, it is expected that, with a longer observation time, it is possible to reach similar levels of bone formation among the groups. The results demonstrating a superiority of autograft in the parameters analyzed (NBT and OA) also corroborate the literature ${ }^{32-37}$.

Platelet-rich plasma was used as scaffold due to the fact that it is an autogenous element, easy to obtain and one that has in its composition inflammatory response mediator factors and adjuvants in the wound healing process (PDGF, TGF- $\beta$, IGFs), besides its adhesive capacity. However, the materials used as scaffold in the literature have the common characteristic of the presence of micropores in their structure, which benefits and generates a stimulus to the graft cells. That may have been a factor, besides the use of undifferentiated ADSC, through which the grafts did not have a superior result in relation to autograft.

Di Bella et $a .^{30}$ reported that large pores are necessary to guarantee vascular growth and tissue formation. A highly interconnected network of micropores is necessary to allow cellcell communication. Moreover, pores between 250 and $400 \mu \mathrm{m}$ prove to be cellular adhesion and tissue formation conductive.

It may be necessary to assess the PRP not as the main scaffold, but as adjuvant, for its growth factors, to other materials [lyophilized bone, poly lactic glycolic acid, bone morphogenetic protein (BPM)]. According to Tobita $^{38}$, the effectiveness of the PRP in the bone regeneration is not clear, 
Reconstruction of parietal bone defects with adipose-derived mesenchymal stem cells. Experimental study Silva DD et al.

particularly because the PRP does not present BMP, which is a more potent osteoinductive protein that promotes the differentiation of stem cells for the osteoblastic lineage and that can induce the bone formation, including the ectopic.

Papaverine is a potent vasodilator and has been used to improve circulation in expanded skin flaps. Thus, its vasodilating action could improve vascular bed, facilitating the integration of the graft and decreasing the hypoxia caused in the tissues by the surgical act. In experimental works, its topic use decreased the function of the myofibroblasts and improved circulation ${ }^{39}$. Papaverine also increases the blood flow of microvascular anastomosis ${ }^{40,41}$. However, no significant effect was found among the groups with or without the addition of papaverine, either in 14 or 28 days. There was bone regeneration in all the groups but without statistical difference with the addition of the studied components (ADSC, papaverine and PRP), nor between the studied periods (14 versus 28 days). Further research with longer follow up periods is necessary to clarify this issue.

\section{- Conclusion}

Experimental parietal bone reconstruction, combining MSC, PRP, and papaverine presented regeneration in all the groups with no significant difference among them.

\section{- References}

1. Chang SC-N, Wei FC, Chuang $H$, Chen YR, Chen JK, Lee $\mathrm{KC}$, Chen PKT, Tai CL, Lou J. Ex vivo gene therapy in autologous critical-size craniofacial bone regeneration. Plast Reconstr Surg. 2003;112(7):1841-50. https://doi.org/10.1097/01. PRS.0000091168.73462.1A

2. Flynn LE, Woodhouse KA. Adipose tissue engineering with cells in engineered matrices. Organogenesis. 2008;4(4):228-35. https://doi.org/10.4161/org.4.4.7082

3. Cowan CM, Shi Y-Y, Aalami OO, Chou Y-F, Mari C, Thomas R, Quarto N, Contag CH, Wu B, Longaker MT. Adipose-derived adult stromal cells heal critical-size mouse calvarial defects. Nat Biotechnol. 2004;22(5):560-7. https://doi.org/10.1038/ nbt958

4. Scherberich A, Müller AM, Schäfer DJ, Banfi A, Martin I. Adipose tissue-derived progenitors for engineering osteogenic and vasculogenic grafts. J Cell Physiol. 2010;225(2):348-53. https:// doi.org/10.1002/jcp.22313

5. Flynn LE, Prestwich GD, Semple JL, Woodhouse KA. Adipose tissue engineering with naturally derived scaffolds and adiposederived stem cells. Biomaterials. 2007;28(26):3834-42. https:// doi.org/10.1016/j.biomaterials.2007.05.002

6. Flynn LE, Prestwich GD, Semple JL, Woodhouse KA. Proliferation and differentiation of adipose-derived stem cells on naturally derived scaffolds. Biomaterials. 2008;29(12):1862-71. https:// doi.org/10.1016/j.biomaterials.2007.12.028

7. Zhu Y, Liu T, Song K, Fan X, Ma X, Cui Z. Adipose-derived stem cell: a better stem cell than BMSC. Cell Biochem Funct. 2008;26(6):664-75. https://doi.org/10.1002/cbf.1488
8. Zuk PA, Zhu M, Mizuno $\mathrm{H}$, Huang JI, Futrell JW, Katz AJ, Benhaim P, Lorenz HP, Hedrick MH. Multilineage cells from human adipose tissue: implications for cell-based therapies. Tissue Eng. 2001;7(2):211-28. https://doi. org/10.1089/107632701300062859

9. Zuk PA, Zhu M, Ashjian P, Ugarte DA, Huang Jl, Hiroshi M, Alfonso ZC, Fraser JK, Benhaim P, Hedrick MH. Human adipose tissue is a source of multipotent stem cells. Mol Biol Cell. 2002;13(12):4279-95. https://doi.org/10.1091/mbc. e02-02-0105

10. Levi B, James AW, Nelson ER, Vistnes D, Wu B, Lee M, Gupta A, Longaker MT. Human adipose derived stromal cells heal critical size mouse calvarial defects. PLoS One. 2010;5(6):e11177. https://doi.org/10.1371/journal.pone.0011177

11. Yoon E, Dhar S, Chun DE, Gharibjanian NA, Evans GRD. In vivo osteogenic potential of human adipose-derived stem cells/ poly lactide-co-glycolic acid constructs for bone regeneration in a rat critical-sized calvarial defect model. Tissue Eng. 2007;13(3):619-27. https://doi.org/10.1089/ten.2006.0102

12. Lendeckel $S$, Jodicke $A$, Christophis $P$, Heidinger K, Wolff J, Fraser JK, Hedrick MH, Berthold L, Howaldt HP. Autologous stem cells (adipose) and fibrin glue used to treat widespread traumatic calvarial defects: case report. J Craniomaxillofac Surg. 2004;32(6):370-3. https://doi.org/10.1016/j.jcms.2004.06.002

13. Marx RE. Platelet-rich plasm: evidence to support its use. J Oral Maxillofac Surg. 2004;62(4):489-96. https://doi.org/10.1016/j. joms.2003.12.003

14. Crovetti G, Martinelli G, Issi M, Barone M, Guizzardi M, Campanati B, Moroni M, Carabelli A. Platelet gel for healing cutaneous chronic wounds. Transfus Apher Sci. 2004;30(2):14551. https://doi.org/10.1016/j.transci.2004.01.004

15. Whitman DH, Berry RL, Green DM. Platelet gel: an autologous alternative to fibrin glue with applications in oral and maxillofacial surgery. J Oral Maxillofac Surg. 1977;55(11):12949. https://doi.org/10.1016/S0278-2391(97)90187-7

16. Anitua E. Plasma Rich in growth factors: preliminary results of use in the preparation of future sites for implants. Int J Oral Maxillofac Implants. 1999;14(4):529-35.

17. Lynch SE, Genco R, Marx R. Tissue engineering: applications in maxillofacial surgery and periodontics. Illinois: Quintessence Publishing; 1999.

18. Lindemann S, Tolley ND, Dixon DA, Mclntyre TM, Prescott SM, Zimmerman GA, Weyrich AS. Activated platelets mediate inflammatory signaling by regulated interleukin $1 \beta$ synthesis. J Cell Biol. 2001;154(3):485-90. https://doi.org/10.1083/jcb.200105058

19. Efeoglu C, Akçay YD, Ertürk S. A modified method for preparating platelet-rich plasma: an experimental study. J Oral Maxillofac Surg. 2004;62(11):1403-7. https://doi.org/10.1016/j.joms.2004.06.047

20. Green DM, Klink B. Platelet gel as an intraoperatively procured platelet-based alternative to fibrin glue. Plast Reconstr Surg. 1998;101(4):1161-2.

21. Anitua $E$. The use of plasma-rich growth factors (PRGF) in oral surgery. Pract Proced Aesthet Dent. 2001;13(6):487-93.

22. Bhanot $\mathrm{S}$, Alex JC. Current applications of platelet gels in facial plastic surgery. Facial Plast Surg. 2002;18(1):27-33. https://doi. org/10.1055/s-2002-19824

23. Linkhart TA, MohanS, BaylinkDJ. Growth factors for bone growth and repair: IGF, TGF $\beta$, and BMP. Bone. 1996;19(1 Suppl):1S12S. https://doi.org/10.1016/S8756-3282(96)00138-X 
24. Man D, Plosker H, Winland-Brown JE. The use of autologous platelet-rich plasma (platelet gel) and autologous platelet-poor plasma (fibrin glue) in cosmetic surgery. Plast Reconstr Surg. 2001;107(1):229-39. https://doi.org/10.1097/00006534200101000-00037

25. Batouli S, Miura M, Brahim J, Tsutsui TW, Fisher LW, Gronthos S, Robey PG, Shi S. Comparison of stem-cell-mediated osteogenesis and dentinogenesis. J Dent Res. 2003;82(12):97681. https://doi.org/10.1177/154405910308201208

26. Sonnleitner D, Huemer $P$, Sullivan DY. A simplified technique for producing platelet-rich plasma and platelet concentrate for intraoral bone grafting techniques: a technical note. Int J Oral Maxillofac Implants. 2000;15(6):879-82.

27. Portinho CP, Collares MVM, Silva FH, Nardi NB, Pinto RD, Siqueira E, Morellat G, Sumino K. Reconstrução de calota craniana com células-tronco mesenquimais indiferenciadas: estudo experimental. Rev Bras Cir Plast. 2006;21(3):161-5.

28. Peptan IA, Hong L, Mao JJ. Comparison of osteogenic potentials of visceral and subcutaneous adipose-derived cells of rabbits. Plast Reconstr Surg. 2006;117(5):1462-70. https://doi. org/10.1097/01.prs.0000206319.80719.74

29. Cui L, Liu B, Liu G, Zhang W, Cen L, Sun J, Yin S, Liu W, Cao Y. Repair of cranial bone defects with adipose derived stem cells and coral scaffold in a canine model. Biomaterials. 2007;28(36):5477-86. https://doi.org/10.1016/i.biomaterials.2007.08.042

30. Di Bella C, Farlie P, Penington AJ. Bone regeneration in a rabbit critical-sized skull defect using autologous adipose-derived cells. Tissue Eng Part A. 2008;14(4):483-90. https://doi. org/10.1089/tea.2007.0137

31. Jabbarzadeh E, Starnes T, Khan YM, Jiang T, Wirtel AJ, Deng M, Ly Q, Nair LS, Doty SB, Laurecin CT. Induction of angiogenesis in tissue-engineered scaffolds designed for bone repair: $A$ combined gene therapy-cell transplantation approach. Proc Natl Acad Sci USA. 2008;105(32):11099-104. https://doi. org/10.1073/pnas.0800069105

32. Alberius $P$, Isaksson $S$, Klinge $B$, Sjögren $S$, Jönsson J. Regeneration of cranial suture and bone plate lesions in rabbits. Implications for positioning of osteotomies. J Craniomaxillofac Surg. 1990;18(6):2719. https://doi.org/10.1016/S1010-5182(05)80430-5

33. Perry CR. Bone Repair techniques, bone graft and bone graft substitutes. Clin Orthop Rel Res. 1999;360:71-86. https://doi. org/10.1097/00003086-199903000-00010
34. DeLuca L, Raszewski R, Tresser N, Guyuron B. The fate of preserved autogenous bone graft. Plast Reconstr Surg. 1997;99(5):1324-8. 199704001-00019

35. Lemperle SM, Calhoun CJ, Curran RW, Holmes RE. Bony healing of large cranial and mandibular defects protected from softtissue interposition: a comparative study of spontaneous bone regeneration, osteoconduction, and cancellous autografting in dogs. Plast Reconstr Surg. 1998;101(3):660-72. https://doi. org/10.1097/00006534-199803000-00013

36. Conrad C, Huss R. Adult stem cell lines in regenerative medicine and reconstructive surgery. J Surg Res. 2005;124(2):201-8. https://doi.org/10.1016/i.jss.2004.09.015

37. Yoneda $M$, Terai $H$, Imai $Y$, Okada $T$, Nozaki $K$, Inoue $H$, Miyamoto S, Takaoka K. Repair of an intercalated long bone defect with a synthetic biodegradable bone-inducing implant. Biomaterials. 2005;26(25):5145-52. https://doi.org/10.1016/i. biomaterials.2005.01.054

38. Tobita M, Uysal AC, Ogawa R, Hyakusoku $H$, Mizuno $H$. Periodontal tissue regeneration with adipose-derived stem cells. Tissue Eng Part A. 2008;14(6):945-53. https://doi. org/10.1089/ten.tea.2007.0048

39. Luan J, Tang Y, Yang P /, Zhang X, Hou D, Ma G, Wang Q. Experimental study on enhancement of tissue expansion with papaverine cream. Zhonghua Zheng Xing Wai Ke Za Zhi. 2002;18(1):29-32.

40. Evans GR, Gherardini G, Gurlek A, Langstein H, Joly GA, Cromeens DM, Sukumaran AV, Williams J, Kilbourn RG, Wang $B$, Lundeberg T. Drug-induced vasodilation in an in vitro and in vivo study: the effects of nicardipine, papaverine, and lidocaine on the rabbit carotid artery. Plast Reconstr Surg. 1997;100(6):1475-81. https://doi.org/10.1097/00006534199711000-00015

41. Gherardini G, Gürlek A, Cromeens D, Joly GA, Wang B-G, Evans GR. Drug-induced vasodilation: in vitro and in vivo study on the effects of lidocaine and papaverine on rabbit carotid artery. Microsurgery. 1998;18(2):90-6. https:// doi.org/10.1002/(SICI)1098-2752(1998)18:2\%3C90::AIDMICR6\%3E3.0.CO;2-Y

\section{Correspondence:}

Diego da Silva Dias

Programa de Pós-Graduação em Medicina: Ciências Cirúrgicas

Faculdade de Medicina da UFRGS

Rua Ramiro Barcelos, 2400/2ㅇaㅁ andar

90035-903 Porto Alegre - RS Brasil

drdiegodias@gmail.com

Received: Aug 12, 2020

Review: Oct 10, 2020

Accepted: Nov 09, 2020
Conflict of interest: none

Financial source: FIPE/HCPA

This is an Open Access article distributed under the terms of the Creative Commons Attribution License, which permits unrestricted use, distribution, and reproduction in any medium, provided the original work is properly cited.

${ }^{1}$ Research performed at Animal Research Center, Hospital de Clínicas de Porto Alegre (HCPA), Universidade Federal do Rio Grande do Sul (UFRGS), Porto Alegre-RS, Brazil. 